\title{
It's not how old you are but how you are old: A review on aging and consumer behavior
}

\author{
Robert Zniva $^{1}$ - Wolfgang Weitzl ${ }^{2}$
}

Received: 14 April 2016 / Accepted: 12 December 2016 / Published online: 18 January 2017

(C) The Author(s) 2017. This article is published with open access at Springerlink.com

\begin{abstract}
The paper presents a review of 128 studies on the behavior of older consumers published in the last 35 years (from 1980 to 2014) in 35 peer-reviewed journals. The purpose of the procedure is twofold: First, we aim to summarize results on agerelated changes in consumer research. Second, by doing so, we evaluate the relative importance of age-related factors (chronological, biological, psychological, and social age as wells as life events and life circumstances) in research on older consumers. Results of the review show that research on older consumers is still dominated by investigations using chronological age. Influences of other aspects of the aging process, although recommended by previous research reviews and providing valuable insights, are still playing a minor role in the investigation of consumer behavior. Research with alternative age measures is still in an early, exploratory stage and future studies should include specific aspects as well as multitheoretical models of aging.
\end{abstract}

Keywords Older consumers · Aging · Consumer behavior

\section{JEL Classsification M31}

Electronic supplementary material The online version of this article (doi:10.1007/s11301-016-0121-z) contains supplementary material, which is available to authorized users.

$凶$ Robert Zniva

robert.zniva@wu.ac.at

1 Institute for Retailing and Marketing, Department of Marketing, Vienna University of Economics and Business, Welthandelsplatz 1, Vienna, Austria

2 University of Vienna, Vienna, Austria 


\section{Introduction}

According to the projections of the United Nations (2013), the world is aging at an unprecedented rate. In the United States and Europe substantial growth in the segment of older adults is expected in the next two decades. Persons aged 65 or over represent the fastest-growing demographic segment, estimated to peak at a level of 70 million in the United States by 2030 (Greenberg 2011) and 160 million in the European Union in 2050 (Vienna Institute of Demography (VID) and International Institute forApplied Systems Analysis (IIASA) 2016). Besides its sheer size and expected growth, the older consumer group is also attractive because of its prosperity. In 2010 the US baby boomer segment had a median household income of $\$ 54,170$, consuming goods and services totaling around $\$ 2$ trillion per year (Ferguson and Brohaugh 2010). A study by AT Kearney (2010) shows that worldwide consumers aged 60 spent $\$ 8$ trillion in 2010 and are projected to spent $\$ 15$ trillion in 2020. Due to this increasing relevance of senior consumers, marketing researchers are interested in how aging affects behavior of the elderly, and how these behavioral changes influence marketing efforts.

Consequently, several reviews on the influence of aging in consumer behavior have been written in the past 40 years, showing the development of the research field. Starting in the 1970s the first reviews summarized descriptive studies explaining the size and growth of the market of elderly customers (Klippel 1974), or discussed first insights on aging and decision making in other research areas like gerontology or psychology and how they influence research in consumer behavior (Phillips and Sternthal 1977). Later on, in the 1980s, several reviews focused on summarizing empirical results from studies, which examined discrepancies in behavior and/or decision making due to chronological age (e.g. Schewe 1984; Tynan and Drayton 1985). In this context, Tongren (1988) demonstrated that results on behavioral differences between older and younger consumers are not consistent. Based on the notion that chronological age (age measured in years lived) alone cannot explain the heterogeneity of the behavior of older consumer groups, reviews in the 1990s started focusing on different aspects of the aging process. Moschis $(1991,1994)$ introduced a multidimensional view on the aging process by reviewing different aging theories. According to these theories, the aging process consists of a biological, psychological, and social dimension. Gregoire (2003) used the work of Moschis (1994) to summarize empirical findings and establish a multidimensional research focus on aging in the field of consumer behavior. He proposed the development of theories, which focus on those relevant biological, psychological or social age-related changes, which determine consumer behavior. A proposition, followed especially by research on decision-making processes of older consumers where psychologically age-related changes provided a solid basis for theory development (Yoon et al. 2009). However, Moschis (2012) questioned in his latest review the research focus on specific dimensions of aging and other age-related factors, showing that there is a discrepancy between opinions on how the field of research on the behavior of older consumers should advance in the future.

The purpose of the paper at hand is to shed light on this discrepancy by structurally, quantifying and verifying what is known on the impact of aging on consumer behavior. All mentioned previous reviews, with the exception of Tongren (1988), can be classified as "coverage of pivotal works" (Cooper 1988) or as "traditional review" 
Table 1 Search term combinations

\begin{tabular}{|c|c|c|c|c|}
\hline 1. Search term & Operator & 2. Search term & & \\
\hline \multirow{14}{*}{$\begin{array}{l}\text { Marketing } \\
\text { OR } \\
\text { Consumer behavior }\end{array}$} & \multirow[t]{14}{*}{ AND } & Adult(s) & Old & $60+$ \\
\hline & & Age & Older & $65+$ \\
\hline & & Aging & Older people & $70+$ \\
\hline & & Baby boomers & Older consumer(s) & $75+$ \\
\hline & & Best ager & Older customer(s) & $80+$ \\
\hline & & Elderly & Retiree(s) & $45+$ \\
\hline & & Elderly consumer(s) & Selpies & $50+$ \\
\hline & & Elderly customer(s) & Senior(s) & $55+$ \\
\hline & & Grey & Senior citizen(s) & $60+$ \\
\hline & & Grey market & Silver surfer & $65+$ \\
\hline & & Master consumers & Woopies & $70+$ \\
\hline & & Mature & $45+$ & $75+$ \\
\hline & & Mature consumer & $50+$ & $80+$ \\
\hline & & Mature customer & $55+$ & \\
\hline
\end{tabular}

(Booth et al. 2012). They present a structured analysis of central results, but do not provide a picture of the general body of knowledge of the topic under investigation. Furthermore, they do not clarify the quality of conduct of the review. In this context, Mulrow (1994) and Booth et al. (2012) argue that the incomplete reporting of methods can lead to several methodological flaws and bias conclusions of reviews. The paper at hand avoids these methodological weaknesses and presents a systematic review of studies using quantitative research designs to investigate the behavior of older consumers published in 35 years (from 1980 to 2014). The aim of the study is to create an exhaustive, transparent body of knowledge on what is quantitatively validated regarding age related changes in consumer research. By doing so, we clarify the current stage of research on older consumers and assess the present and future importance of different aspects of the aging process for knowledge creation in consumer behavior.

\section{Methodology of the review}

A literature review is a "systematic, explicit, and reproducible method for identifying, evaluating, and synthesizing the existing body of completed and recorded work" (Fink 2010, p. 3). In this section, we outline the stepwise procedure for searching, filtering, categorizing, and analyzing publications on the topic of older consumers. The review at hand can be classified as state of the art review on the topic of consumer behavior of older people. It follows a procedure proposed by Fink (2010). As a first step, we conducted a rigorous literature search using the term "marketing" or "consumer behavior" in combination with 41 keywords related to aging (see Table 1).

The aim of the literature search is to identify all peer reviewed journal articles published on the topic between 1980 and 2014. The cut-off year of 1980 was selected due to a statement by Moschis (2003), who indicated that older consumers where not 
Table 2 Descriptive categories (partially based on Sachan and Datta (2005))

\begin{tabular}{llll}
\hline Sample design & Research design & Research method & Data analysis technique \\
\hline Convenience sample & Empirical quantitative & Experiment & Analysis of (co)variance \\
Judgement sample & Empirical triangulation & Focus groups & Chi-square \\
Quota sample & Interview & Cluster analysis \\
Random sample & Panel & Correlation \\
Not indicated & Survey & Descriptive statistics \\
& World café & Discriminant analysis \\
& & Factor analysis \\
& & Logit model \\
& & Non-parametric-tests \\
& & Regression \\
& & Structural equation model \\
& & T-test \\
\end{tabular}

treated as an independent market segment before the 80ies. The search was conducted using two databases (AB/Inform Proquest and EBSCO Business Source Premier). In total 164 searches were conducted and produced more than 200,000 hits as a first result. In a second step, we screened the titles and abstracts of all identified articles and selected only articles dealing with the older consumer group. In addition, the quality of the identified journals was assessed. Only articles published in peer-reviewed journals, which were ranked in the Hartzing Journal Quality List (2015) were considered as appropriate for the review at hand. Furthermore, since the aim of the review is to provide an overview on the quantitatively validated influences of aging on consumer behavior, only studies with quantitative research designs were considered for further analysis. Studies solely using qualitative research designs were not included in the review. Using the above mentioned selection criteria, we identified 128 studies. A list of all identified articles can be found in the web appendix.

\subsection{Descriptive analysis of the sample}

To describe the identified studies from a methodological point of view we used a categorization implemented by Sachan and Datta (2005). Besides basic information (e.g. the name of author(s), country of origin, name of journal, purpose of the study, sample design), the research design, research method, and data analysis technique was categorized. Table 2 provides an overview of the most important categories and subgroups.

\subsection{Content analysis of the sample}

In addition to the descriptive analysis of the sample, we also used content analysis to gain a deeper understanding of the identified literature. Therefore, a deductive, structuring content analysis approach by Mayring (2010) was implemented. In a first step, we 


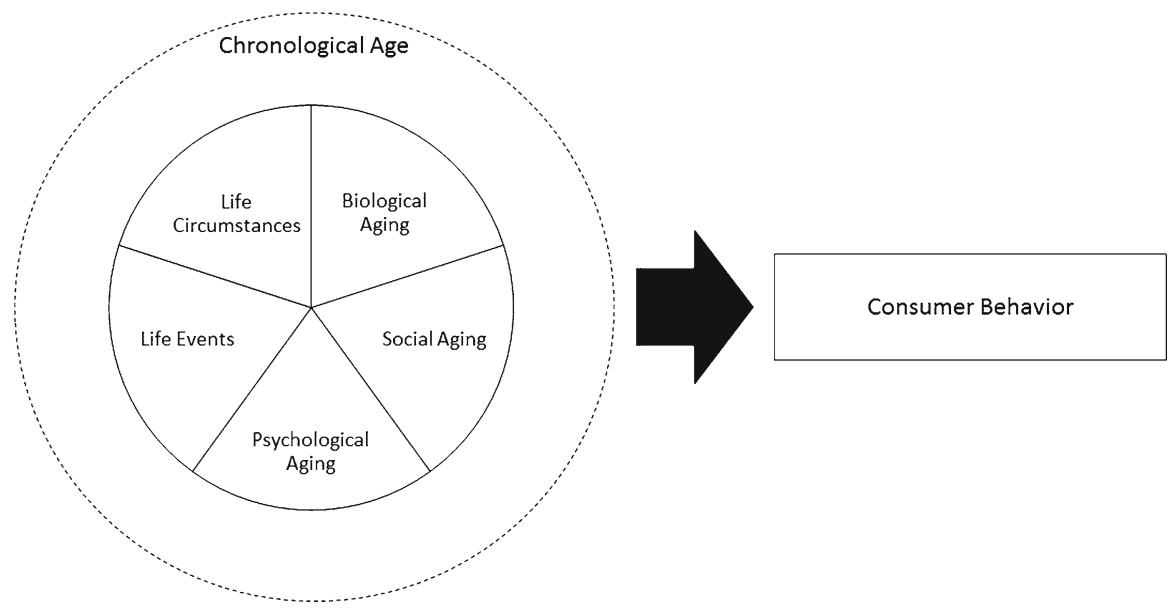

Fig. 1 Categorization of age-related factors

identified all age-related dependent and all consumer-behavior-related independent variables in the studies. In a second step, we categorized all dependent age-related variables according to a framework proposed by Moschis (2012) and Moschis et al. (2011). The aging process is grouped into three broad categories: (1) biological aging processes, (2) psychological aging processes, and (3) social aging processes. These so called aging dimensions are accompanied by (4) life events and (5) life circumstances and form together the so called age-related factors shown in Fig. 1. According to Moschis (2012) and other authors (e.g. Moschis 1996; Gregoire 2003; Mathur and Moschis 2005; Moschis and Pettigrew 2010) age-related factors influence older consumers' responses to products and services.

(1) Biological aging, according to Moschis (1994), refers to "the changes in human functional capacity resulting from changes in cells and tissues that in turn cause deterioration of the biological system and its subsystems". They typically include changes in body systems (e.g. decline in vision and hearing) and age-related chronic conditions and diseases (Gregoire 2003). Physiological changes typically affect the way older consumers experience products, services, and marketing offerings.

(2) Psychological aging involves changes in cognition, personality, and the self (Moschis 2012). Older adults typically tend to exhibit declines in memory and cognition when compared to younger adults. Although these declines depend strongly on personal and environmental factors and not all facets of cognition are affected equally (Yoon et al. 2009), research results show that they can influence consumer reactions on marketing activities. Furthermore, psychological aging involves changes in personality and the self. One indicator of these changes is self-perceived age. Older people think, feel, and act younger than they chronologically are, due to difficulties in adapting their self-perception to changes in later life. Differences in self-perceived age have an influence on responses to products and retail offerings (Moschis and Mathur 2006; Teller et al. 2013). 
(3) Social aging refers to changes of roles experienced by people while aging. As a result of role enactment older people assume their new roles as e.g. grandparents or retirees and develop new needs for products and services (Moschis 2012).

(4) Life events are random (e.g. major accident, natural disaster) or programmed (e.g. empty nest) experiences, which can occur at different ages and affect attitude and behavior of people experiencing them (Moschis 2012; Andreasen 1984; Murrell et al. 1988). People in their 40s, 50s, and 60s in particular experience a host of life events (Silvers 1997), which can be positive (e.g. birth of the grandchild) or negative (e.g. death of a spouse) and influence lifestyles and consumption patterns (Andreasen 1984; Mathur et al. 2003, 2008). Typical life events are for example transitions into old-ageroles like retirement (social), the onset of chronic conditions (biological) or stress due to the loss of a loved one (psychological) and can affect all previously mentioned aging dimensions (Moschis 2012).

(5) Life circumstances are cohort, historical, and environmental factors, which are independent from aging processes, shape shopping habits, and are likely to influence consumption patterns of individuals in older age brackets (Moschis 2012; Moschis and Mathur 2007). For example, older US baby boomers grew up in times when novelty and experimentation had a high priority and therefore, they are more open towards new products and services (Moschis et al. 2011).

Although every age-related factor was explained separately, a strong interdependence between the factors is assumed (Moschis 2012; Gregoire 2003). To illustrate this interdependence the different factors are grouped together in Fig. 1.

For completeness, chronological age was also included in the framework. It is seen in this review as a meta-measure, which tries to describe the status of a person on all previously mentioned processes. Due to the multidimensionality of these factors, chronological age is believed to have little explanatory power (Moschis 2012). A 60year-old person, who was socialized in the US, can be very healthy, may have no relevant declines in cognitive functions, didn't experience a lot of life events lately, feels and acts very young and can be grandparent and retiree. In contrast, another 60year old, socialized in Eastern Europe, has chronic diseases, experienced a lot of life events lately and also a strong decline in cognition, feels already quite old but nevertheless he/she is still working. Both persons are 60 , but will differ strongly in lifestyle and consumption due to their individual aging processes, life events and life circumstances. Literally, every combination of different facets of age-related factors seems possible at a specific chronological age explaining poorly the heterogeneity within the older consumer group. However, as a standard demographic variable chronological age is still the most widely used measure to explain changes in older consumer behavior. Therefore, it is also considered in the review at hand.

In the third and last step of the content analysis the investigated consumer behavior variables were also grouped into three broad categories. Following the procedure of Gregoire (2003) based on typical consumer behavior models like Engel et al. (1968), consumer responses were categorized in: (1) affective and individual responses, (2) cognitive responses, and (3) behavioral responses (see Fig. 2). 


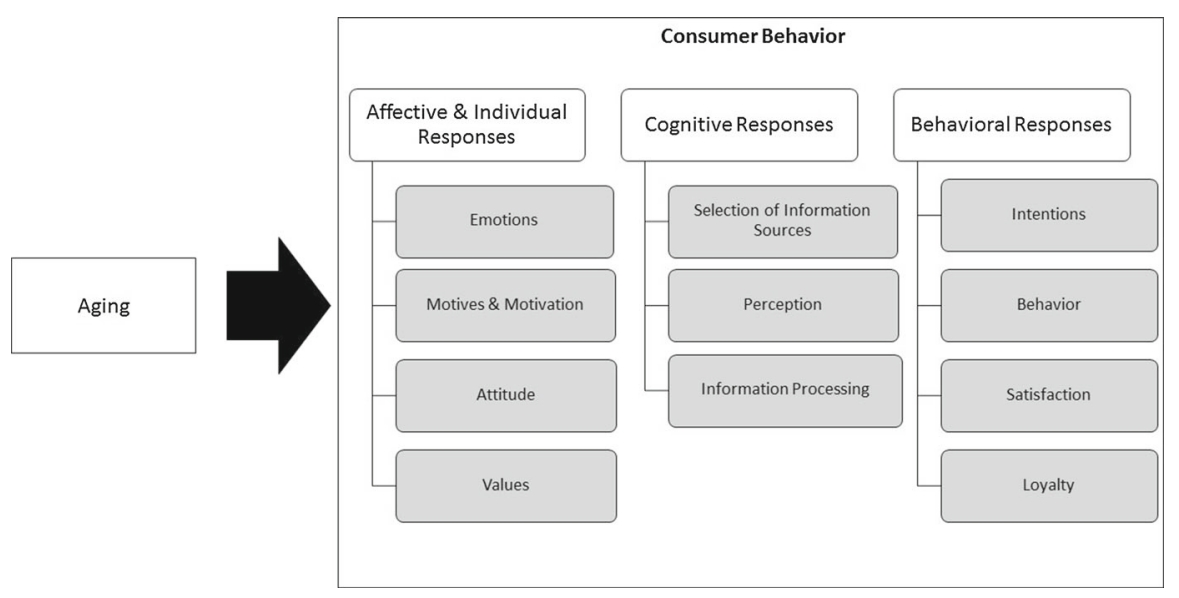

Fig. 2 Categorization of consumer responses

(1) The affective and individual responses consist of all the emotional influences a consumer is confronted with when deciding to buy or consume. It includes constructs which are typically associated with the personality of a consumer. Different kinds of emotions, attitudes, values, and motivations are researched in this context.

(2) The cognitive responses include variables related to consumer information processing. This includes the stages in which an individual becomes conscious of a problem, collects information, and analyzes the information before buying or consuming a service or a product. Typical constructs investigated in this category are, for example, awareness, recognition, recall, and knowledge of brands, product and information sources.

(3) The behavioral responses encompass the physical actions related to buying and consuming a product or a service. Characteristic constructs are behavioral variables like purchase behavior or usage, but also constructs strongly related to behaviors like loyalty or intentions to buy. In addition, the construct of satisfaction was included in this category because it can be considered as a direct outcome of buying and consuming (Engel et al. 1968).

The chosen qualitative categories of age-related factors and consumer behavior variables go in line with previous literature reviews (e.g. Tongren 1988; Gregoire 2003). In the next sections, the results of our literature review are presented.

\section{Descriptive results}

More than 50 percent of all identified studies were conducted in the US, followed by the UK and Finland (see Table 3). One possible reason for this US dominance lies in the history of marketing as a research field. Marketing research as a scientific discipline was established in the early 20th century in the US and has experienced professional development there (Wilkie and Moore 2003). Hence, the research field is guided and 
Table 3 Identified countries of origin of studies

\begin{tabular}{lcl}
\hline Countries & Number & Percentage $(\%)$ \\
\hline USA & 75 & 58.6 \\
UK & 14 & 10.9 \\
Finland & 6 & 4.7 \\
Australia & 6 & 4.7 \\
France & 5 & 3.9 \\
Malaysia & 4 & 3.1 \\
Japan & 3 & 2.3 \\
Germany & 3 & 2.3 \\
Austria & 2 & 1.6 \\
Belgium & 1 & 0.8 \\
Canada & 1 & 0.8 \\
China & 1 & 0.8 \\
Corea & 1 & 0.8 \\
Sweden & 1 & 0.8 \\
Southafrica & 1 & 0.8 \\
Multiple countries & 4 & 3.1 \\
\hline Total & 128 & 100 \\
\hline & & \\
\hline
\end{tabular}

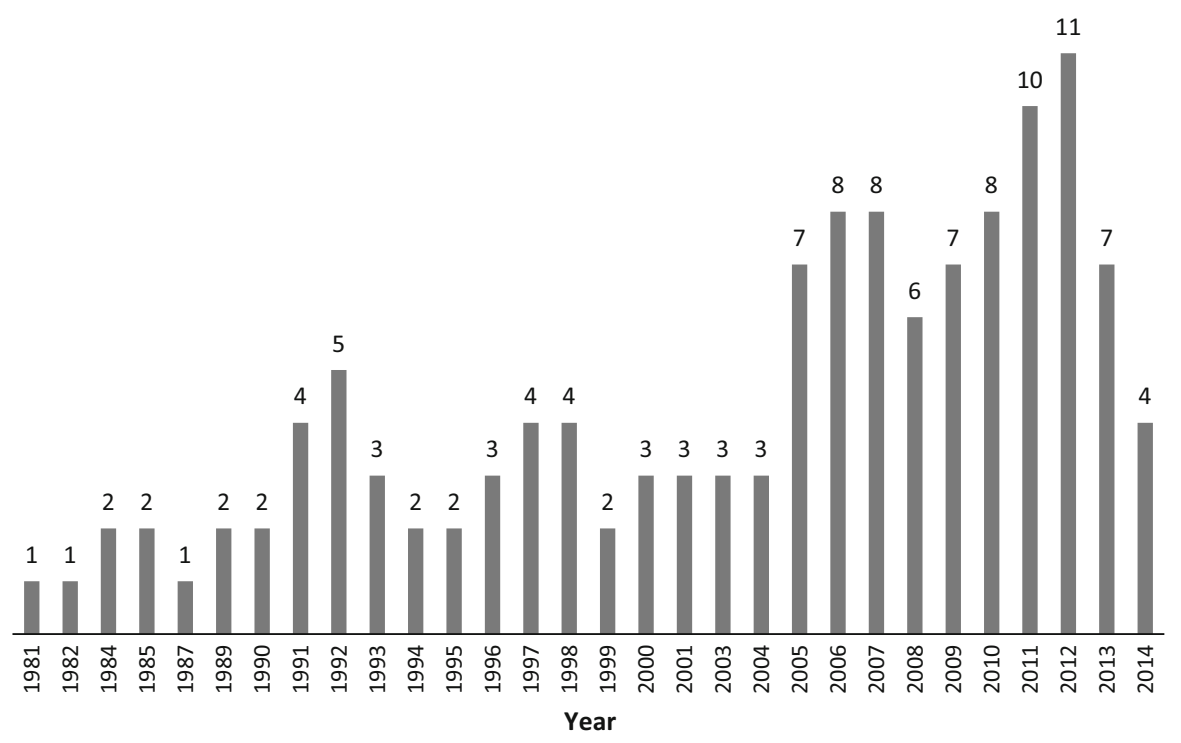

Fig. 3 Number of identified publications per year

strongly influenced by US marketing associations (e.g. American Marketing Association, Association for Consumer Research, Academy of Marketing Science) and their publications, fostering a US dominance in marketing research. 
A second reason for the US-dominance is the time of appearance of the baby boomer generation. The baby boom started in the US in 1946 right after the second world war and ended 1964 with the introduction and commercialization of the birth control pill. Other countries (especially European countries) were more affected by the destruction of the second world war and needed a longer time to recover and had therefore later baby booms (e.g. Austria 1957-1970). Consequently, the US has one of the oldest baby boomer generations, leading to higher focus on this group in research. A development which can be also seen when analyzing the number of publications per year. Research in European countries (accounting for $25 \%$ of all identified studies) and other non-US countries was mostly done in the 21 st century and also accounts for the peak in number of publications starting between 2005 and 2013 (see Fig. 3). Table 4 provides an overview of the sample designs, research designs, research methods, and data analysis techniques used in all identified studies.

Most of the identified articles used pure empirical quantitative research designs (115 articles), only a few implemented empirical triangulations (9 articles) and combined qualitative and quantitative research. Consequently, the main research methods used were surveys (114 studies) and experiments (19 studies). In the triangulation studies, additionally qualitative methods like focus groups, interviews, and a world café were implemented. When analyzing the gathered data, the topic of older consumers typically leads to group comparisons (e.g. older vs. younger; old-old vs. young-old), descriptions of the analyzed groups and correlations between aging and dependent variables. Therefore typical data analysis techniques were analysis of variance or covariance (38 studies) and descriptive statistics (27 studies), followed by t-tests, chi-squares, correlations, structural equations models, factor analysis, and regression. Regarding the applied sampling designs most of the drawn samples were convenience samples (81 surveys). Surprisingly only 47 drawn samples were drawn randomly.

Regarding the size of the samples drawn, differences can be observed between research methods (see Table 5). The largest median sample size (884 respondents) can be observed in studies using panel data. The biggest panel investigated had 38,352 respondents, the smallest 263 persons. Studies using surveys had a median sample size of 300 persons. The biggest sample size of a survey had 130,411 respondents. Also, the size of samples used in experiments is quite large. The median sample size is 155 participants and one experiment investigated a number of 3390 people. Surprising is also a study using 768 qualitative interviews. Generally, it can be seen that there is a great variance in sample sizes per research method and some of the identified studies did a noticeable job in recruiting participants or respondents, which is, given the target group, a respectable achievement.

\section{Results on the impact of chronological age on consumer behavior}

As a first result, the usage and impact of chronological age was assessed. Virtually all identified quantitative studies (127 out of 128) used chronological age. The studies can be classified into three groups (see Table 6): the first consists of 45 studies researching the influence of chronological age by examining and comparing the consumer responses of chronologically older and younger consumers. The second group com- 
Table 4 Details of applied methodologies

\begin{tabular}{|c|c|c|c|}
\hline Sample design & Research design & Research method & Data analysis technique \\
\hline $\begin{array}{l}\text { Convenience sample } \\
\text { (83 samples) }\end{array}$ & $\begin{array}{l}\text { Empirical quantitative } \\
\text { (117 articles) }\end{array}$ & $\begin{array}{l}\text { Experiment } \\
\text { (19 studies) }\end{array}$ & Analysis of (co)variance (38) \\
\hline $\begin{array}{l}\text { Judgement sample } \\
\text { (4 samples) }\end{array}$ & $\begin{array}{l}\text { Empirical triangulation } \\
\text { (11 articles) }\end{array}$ & $\begin{array}{l}\text { Focus groups } \\
\text { (5 studies) }\end{array}$ & Descriptive statistics (27) \\
\hline $\begin{array}{l}\text { Quota sample } \\
\text { (8 samples) }\end{array}$ & & Interview (6 studies) & t test (19) \\
\hline \multirow{10}{*}{$\begin{array}{l}\text { Random sample } \\
\text { (48 samples) }\end{array}$} & & Panel (7 studies) & Correlation (19) \\
\hline & & Survey (118 studies) & Factor analysis (18) \\
\hline & & World café (1 study) & Chi-square (17) \\
\hline & & & $\begin{array}{l}\text { Structural equation model } \\
\text { (17) }\end{array}$ \\
\hline & & & Regression (15) \\
\hline & & & Cluster analysis (14) \\
\hline & & & Logit model (5) \\
\hline & & & Non-parametric-tests (5) \\
\hline & & & Discriminant analysis (4) \\
\hline & & & Others (14) \\
\hline
\end{tabular}

Table 5 Description of indicated sample sizes per research method

\begin{tabular}{lrcrrrr}
\hline & Surveys & Experiments & Interviews & Panels & Focus-groups & World café \\
\hline Number of studies & 131 & 18 & 6 & 7 & 2 & 1 \\
Average sample size & 2219 & 398 & 157 & 9244 & 37 & - \\
Median & 300 & 155 & 37 & 884 & 37 & - \\
Maximum & 130,411 & 3390 & 768 & 38,352 & 42 & 46 \\
Minimum & 37 & 48 & 7 & 263 & 32 & 46 \\
\hline
\end{tabular}

prises of 46 studies using chronological age to define the older consumer group and afterwards investigate chronological or non-chronological age influences within the group. The third type of studies includes 36 non-comparative studies, solely defining chronologically older consumer group(s) without comparing them to younger ones or researching any age influence within them.

Especially the last group of studies is a counter-intuitive result. Studies describing solely the consumer responses of a chronologically defined age group run the risk of false interpretations, as pointed out and strongly criticized early by Tongren (1988). They interpret consumer responses as being caused by chronological aging, without proofing whether there is an actual difference in consumer behavior between chronologically older and younger consumers. This critical issue is also not a matter of "ancient" times, but an ongoing matter, as can be seen in Fig. 4. 
Table 6 Description of indicated sample sizes per research method

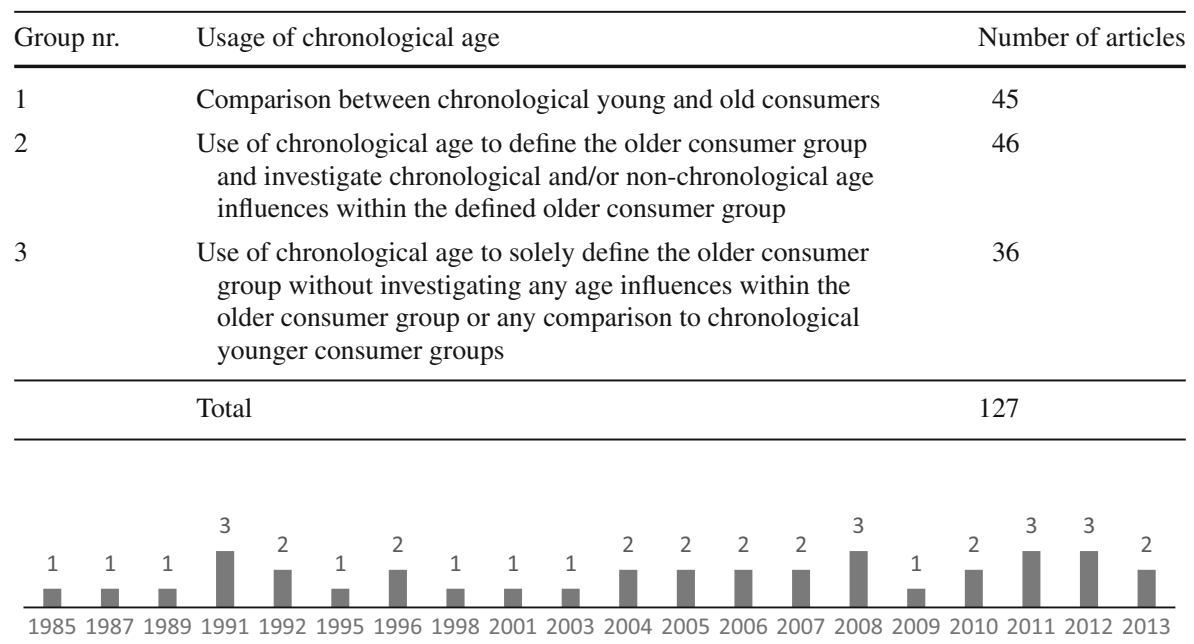

Fig. 4 Articles using chronological age to solely define the older consumer group (per year)

Table 7 Chronological old age limits

\begin{tabular}{llc}
\hline Chronological definition of old age & Number of publications & $\%$ \\
\hline 40 Years or older & 4 & 3 \\
45 Years or older & 1 & $<1$ \\
50 Years or older & 18 & 14 \\
55 Years or older & 32 & 25 \\
60 Years or older & 12 & 9 \\
65 Years or older & 31 & 24 \\
69 Years or older & 1 & $<1$ \\
Multiple chronological old age limits & 7 & $6 \%$ \\
Birth cohorts & 9 & 7 \\
Not indicated & 13 & 10 \\
\hline Total & 128 & 100 \\
\hline
\end{tabular}

Reviewing the different chronological age definitions of older age (Table 7), we could see that the most common old age limit is 55 years or older ( 32 articles) followed by 65 years or older ( 31 articles), replicating a result already conducted by Tongren (1988).

The variations of different chronological old age definitions also confirm Moschis (1996) who stated that the chronological definition of old age depends strongly on the investigated research topic. In this context, chronological age boundaries between 40 years and 69 years can be observed. Reasons for the chosen age limits are presented in Table 8. 
Table 8 Reasons for chronological age limits

\begin{tabular}{|c|c|c|}
\hline Limit & Reasons & Sources \\
\hline $40+$ & $\begin{array}{l}\text { - Definition of baby boomer generation } \\
\text { - Start age for most transitional life } \\
\text { events. }\end{array}$ & Worsley et al. (2011), Ong et al. (2009) \\
\hline $45+$ & $\begin{array}{l}\text { - Start age for most transitional life } \\
\text { events }\end{array}$ & Mathur et al. (1999) \\
\hline $50+$ & $\begin{array}{l}\text { - Most used age limit in relevant } \\
\text { literature } \\
\text { - Age limit used for age-related services } \\
\text { - Typical limit for marketers to define old } \\
\text { age } \\
\text { - Typical limit in general to define old age } \\
\text { - Age limit used by organizations (e.g. } \\
\text { WHO) }\end{array}$ & $\begin{array}{l}\text { Sudbury Riley et al. (2012), Kohlbacher and } \\
\text { Chéron (2012), Jahn et al. (2012), Moschis } \\
\text { and Ong (2011), Kohlbacher and Chéron } \\
\text { (2012), Brennant and Ritch (2010), Sudbury } \\
\text { and Simcock (2009a, b), Tepper (1994) }\end{array}$ \\
\hline $55+$ & $\begin{array}{l}\text { - Most old people accept the age limit } \\
\text { - Other studies use the age limit } \\
\text { - Reviews suggest the age limit } \\
\text { - Age limit used by the census } \\
\text { - People aged } 55 \text { or older share similar } \\
\text { values } \\
\text { - To compare young-old with old-old } \\
\text { - Research of retired persons starts at this } \\
\text { age limit } \\
\text { - To investigate active older people }\end{array}$ & $\begin{array}{l}\text { Ong et al. (2008), Laukkanen et al. (2007); Kim } \\
\text { et al. (2005), Yang et al. (2005), Vuori and } \\
\text { Holmlund-Rytkönen (2005), Kim et al. (2003), } \\
\text { Moschis et al. (2003), Sherman et al. (2001), } \\
\text { Mathur et al. (1998), Keillor et al. (1996), } \\
\text { Burnett (1996), Gentry and Kennedy (1995), } \\
\text { Burt and Gabbott (1995), Moschis et al. } \\
\text { (1993), Fox et al. (1984) }\end{array}$ \\
\hline $60+$ & $\begin{array}{l}\text { - Retirement age in Japan } \\
\text { - Other studies use the age limit }\end{array}$ & Teller et al. (2013) and Singh et al. (2012) \\
\hline $65+$ & $\begin{array}{l}\text { - Other studies use the age limit } \\
\text { - Age limit used by the US census and } \\
\text { official statistics in Finland } \\
\text { - Retirement age in the US } \\
\text { - Age limit were older people still by all } \\
\text { products }\end{array}$ & $\begin{array}{l}\text { Kohijoki (2011), Lee (2011), Nam et al. (2007), } \\
\text { Iyer and Eastman (2006), Miller et al. (1998), } \\
\text { Milliman und Erffmayer (1989) }\end{array}$ \\
\hline
\end{tabular}

Most of the age limits $(50+, 55+, 60+, 65+)$ were chosen because of prior studies using these definitions. Official statistics and census data were a reason for the age limits $50+, 55+$, and $65+$. The age limits $55+, 60+$, and $65+$ can also be considered as typical retirement ages, depending on the county of the investigated studies. Furthermore, the age limits 50+ and 55+ were considered to be the most common ones in marketing research. Very low age limits were mainly chosen when dealing with the impact of transitional life events in marketing or when investigating the baby boomer generation. Generally, the results show that the selection of a chronological age limit to define old age is an arbitrary task and depends strongly on the research question and circumstances of the research project. 
Regarding the influence of chronological age on consumer behavior only results from studies hypothesizing and analyzing the direct influence of chronological age were considered for analysis. Table 9 provides an overview of all studies in the context of consumer behavior and chronological age.

\subsection{Results on the impact of chronological age on affective and individual responses}

In the context of affective and individual consumer responses, research investigated the influence of chronological aging on emotions, motivation, and attitudes. Studies focusing on consumer emotions show that US older consumers prefer emotional, affective advertising appeals (Drolet et al. 2007; Williams and Drolet 2005). However, advertisements communicating negative emotional messages (e.g. ads showing the effect of smoking on health) work with younger consumers, but have an inferior influence on older consumers Jayanti (2010). Furthermore, results of Jahn et al. (2012) indicate that in Germany feelings of "we-ness" (i.e., feelings of being cared for) are more relevant to older people than feelings of "me-ness" (i.e., feelings caused by selfconcept connection) and brand trust. Meneely et al. (2009a, b) show that the enjoyment of food shopping increases with chronological aging in the UK.

Investigations dealing with the influence of chronological age on motivations differ by industry and location. In grocery shopping, for instance, older consumers in the US are motivated by recreation and personal relationships with the retailer (Lumpkin and Greenberg 1982). Furthermore, they prefer close locations and senior discounts when shopping for food or purchasing financial services (Moschis et al. 2004, 2003). In the UK, however, older consumers seek less convenience (e.g. close locations) and search more for healthy products and quality in food shopping (Worsley et al. 2011). When shopping for apparel and furniture in rural areas, chronologically older US consumers are also less driven by moral motivations (Miller et al. 1998).

Studies dealing with the impact of chronological aging on attitudes were also conducted on a multitude of topics. Moschis et al. (1993) shows that in the US consumer attitudes toward marketing stimuli that are age-related (e.g. senior discounts) are more favorable with increasing chronological age. Results of Johnson-Hillery et al. (1997) indicate that US elderly consumers have significantly more positive attitudes towards older retail sales personnel compared to younger retail sales personnel. The studies conducted by Javalgi et al. (2009) and Laukkanen et al. (2007) indicate that older consumers have risk-averse attitudes when it comes to different financial services in the US and Finland. A result refined by Simcock et al. (2006) in the UK, who demonstrate that risks associated with the source of a product (e.g. reputation of a retailer) and the physical performance of a product get more important when getting older. Research on attitudes and stimuli in advertisements suggests that US older adults have generally more positive attitudes towards emotional advertisements (Drolet et al. 2007). Furthermore, Williams and Drolet (2005) show that the type of emotion communicated is moderated through time horizon. Under a limited time horizon (e.g. life is short) older consumers have more positive attitudes towards appeals that avoid negative emotions, under an expansive time horizon (e.g. live forever) appeals which focus on the achievement of positive emotions lead to more positive attitudes (Williams and 


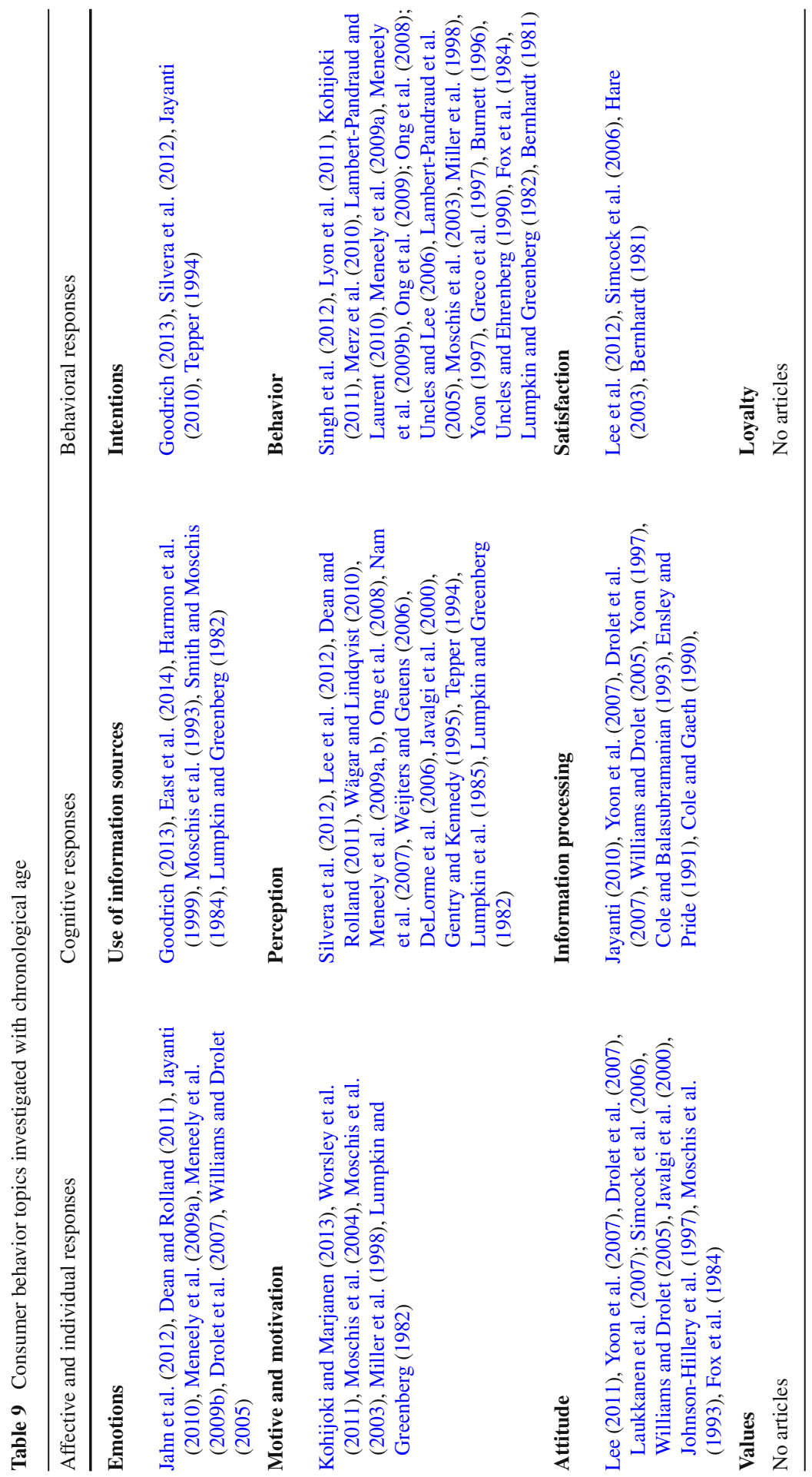


Drolet 2005). Moreover, results by Yoon et al. (2007) show that in the US attitudes are strongly affected by optimal time of day (morning vs. afternoon). In contrast to younger consumers, attitudes of older adults are more strongly affected by an easyto-process criterion (picture relatedness) at their non-optimal time of day (afternoon) and by a more-difficult-to-process criterion (argument strength) at their optimal time of day (morning) (Yoon et al. 2007).

\subsection{Results on the impact of chronological age on cognitive responses}

In terms of cognitive responses, influences of chronological age can be found in all three investigated subcategories. While a notable number of scholars have contributed to our knowledge about the elderly's use of information sources, results remain inconsistent. Lumpkin and Greenberg (1982), for instance, find that US older fashion consumers use newspapers, but do not search for information as active as younger consumers. A result, also supported by Smith and Moschis (1984), who demonstrate that older people interact less with mass media advertising, than their younger counterparts. However, Goodrich (2013) demonstrates that older adults in the US pay more attention to online ads than younger adults. Results by Moschis et al. (1993) and Harmon et al. (1999) find no variation in information source usage among chronological groups. Finally, East et al. (2014), provide some evidence that within the older consumer group in the UK word of mouth (WOM) decreases with an increase in chronological age.

Studies about the impact of chronological aging on perception covered also a multitude of different topics in different locations and industries. In terms of shopping and the perception of store attributes results show that older shoppers in the US perceive knowledgeable store personnel and store reputations as important in apparel shopping and financial services (Javalgi et al. 2000; Lumpkin and Greenberg 1982; Lumpkin et al. 1985). Reliability of the service in US restaurants is also more important to older than younger consumers (Lee and Sontag 2010). In Malaysia, older-elderly (75+) generally perceive durability, quality, after sales service, and environmental friendliness as less important factors when shopping than younger-elderly (55-74 years) (Ong et al. 2008). In Northern Ireland, results by Meneely et al. (2009a, b) indicate a decrease of the importance of multi-purchase promotions, experienced convenience, and nutritional awareness in food shopping. In Australia, older consumers perceive good service, location, and convenience as critical when shopping in pharmacies (Dean and Rolland 2011). In Canada, the opinion of a physician is perceived more important with increasing age, when deciding for a nursing home (Gentry and Kennedy 1995). In service industries, results of Wägar and Lindqvist (2010) indicate that older consumers in Finland experience older customer-contact-persons more favorable. Younger customers prefer older customer-contact-persons only in high-credence services (banking services and dentistry services) (Wägar and Lindqvist 2010). Furthermore, results by Nam et al. (2007) demonstrate that older females in the US have a different perception of fashion than younger consumers (e.g. trousers are more important). Also, when communicating with older consumers, differences become evident. Tepper (1994) shows that within the older US consumer group, younger aged elderly (65+) perceive senior discounts as stigmatization and self-devaluation. A result confirmed by Weijters and 
Geuens (2006) in Belgium for the age-labels "senior", "50+", and "retired". Furthermore, results of Silvera et al. (2012) show that there are differences due to chronological age in the perception of product harm crisis in the US. Older consumers perceive product harm crisis as less severe and see themselves as less vulnerable (Silvera et al. 2012).

In terms of chronological age related changes on information processing, research studies focused on age- related differences in the recall of marketing stimuli and were only conducted in the US. Most of these studies demonstrated a decline in recall with increasing chronological age. Cole and Gaeth (1990), for example, show that older adults are less accurate in their use of nutritional information. Results of Cole and Balasubramanian (1993) indicate a negative correlation between age and working memory capacity, resulting in less accurate decisions when selecting products. Yoon et al. (1997) and (2007) find differences in information processing due to time of the day. More specifically, they conclude that older adults process information more accurate during their optimal time of the day (morning) compared to their non-optimal time of the day (evening) when they rely on schema based processing (Yoon 1997; Yoon et al. 2007). Generally, results indicate that older consumers have a better recall of emotional advertisements (Drolet et al. 2007; Jayanti 2010), especially when the emotions are communicated with an expansive time horizon (e.g. "life is long"). However, when recalling practical marketing information Ensley and Pride (1991) find no difference between elderly and younger subjects.

\subsection{Results on the impact of chronological age on behavioral responses}

In the context of behavioral consumer responses, research investigated the influence of chronological aging on intentions, behavior, loyalty, and satisfaction. Results on the impact of ageing on intentions in the US, show that compared to younger adults, older adults have stronger intentions to purchase and recommend the brand involved in a product harm crisis (Silvera et al. 2012). Furthermore, an influence of the communicated message valence is indicated. Jayanti (2010) demonstrates that especially positive framed messages lead to intentions to adopt healthy life styles in older US consumers (Jayanti 2010). Also, the time of day exerts some influence. Older consumers in the US have a higher purchase intention online later in the day (Goodrich 2013).

Looking at the impact of chronological age on behavior, a variety of topics and results from different countries emerge. When shopping for apparel, Lumpkin and Greenberg (1982) show that older US consumers prefer department and specialty stores. In Northern Ireland, with increasing age people patronize less multiple retailers (Meneely et al. 2009a) and a third of the elderly use the help of others to drive to the store (Meneely et al. 2009b). In Finland, older people do not do their grocery shopping at the store closest to them and patronize super- or hypermarkets because they prefer one-stop shopping trips, a wide product range, and separate service counters (Kohijoki 2011). In the UK, Uncles and Ehrenberg (1990) demonstrate based on their results that within the older consumer group, only the "old-old" have localized and limited shopping habits. Tepper (1994) indicates that senior discount usage increases with age in the US and results of Miller et al. (1998) indicate that older persons shop more 
locally. Regarding the time of day, Yoon et al. (2007) demonstrates that older people in the US prefer to shop for items other than groceries in the late morning or early afternoon (due to late opening hours of non-grocery stores) whereas younger people prefer evening or afternoon hours (Yoon 1997). In Germany, late evening shopping is similarly of minor importance for aged consumers. Instead they prefer to shop in the morning (Merz et al. 2010). When buying a car in France, older consumers consider fewer brands, fewer dealers, and fewer models, and they choose long-established brands more often (Lambert-Pandraud et al. 2005). When buying perfume in France, the older a consumer, the greater are his/her preferences for long-established options. (Lambert-Pandraud and Laurent 2010). In the US financial industry, elderly consumers prefer electronic fund transfers (Moschis et al. 2003). With increasing age the use of long distance calls decreases in the US (Fox et al. 1984). In terms of product categories, results of Uncles and Lee (2006) indicate that there are age-based differences in product category purchasing in Australia (e.g., older consumers are relatively more important in the newspaper category than in retail fuel). In Japan, older consumers buy less beer and less bottled tea (Singh et al. 2012). In Malaysia, spending in recreation, entertainment and cultural services decrease and spending for medical care and health increase with higher chronological age (Ong et al. 2008). Furthermore, people exercise less the older they get (Ong et al. 2008). In communications, results of Greco et al. (1997) show that model age of displays of age-neutral products does not have an effect on purchases.

Results on the impact of chronological aging on satisfaction demonstrate that older elderly (75+) were more likely to be satisfied with the quality of food compared to the younger elderly (65-74) in the UK (Hare 2003). In the US, older consumers are less satisfied with the service quality in restaurants (Lee et al. 2012).

\section{Results on the impact of biological age on consumer behavior}

Biological age measures were used in $12.5 \%$ of the identified studies. Basically, biological age measures can be categorized into two groups. (1) measures assessing the individually experienced health status of respondents and (2) measures assessing biological life events. When measuring subjective health, respondents were typically asked to indicate their general health status on a rating scale (e.g. Le Serre and Chevalier 2012). Other studies relied on measures asking for (chronic) diseases (e.g. Ong and Moschis 2009) or measures indicating health-caused limitations in daily life (e.g. Lee 2011). Biological life events, on the other hand, where measured using a single approach. Respondents were asked which of five life events they have experienced (e.g. lengthy hospitalization or rehabilitation, hearing impairment) in a specific time period and answers were used to build a summated index from zero to five. The higher the index the older is the person's biological age (Mathur and Moschis 2005). Regarding the investigated consumer responses, only studies investigating a direct biological aging effect on consumer behavior were considered. Table 10 provides an overview of all researched consumer behavior areas using biological age.

Interestingly, only one study investigated the impact of biological aging on affective and individual consumer responses. Worsley et al. (2011) investigate the impact 
Table 10 Consumer behavior topics investigated with biological age

\begin{tabular}{lll}
\hline $\begin{array}{l}\text { Affective and individual } \\
\text { responses }\end{array}$ & Cognitive responses & Behavioral responses \\
\hline Emotions & Use of information sources & Intentions \\
No articles & No articles & No articles \\
Motive and motivation & Perception & Behavior \\
Worsley et al. (2011) & DeLorme et al. (2006) & Kohijoki (2011), Mathur and Moschis \\
& & (2005), McMellon and Schiffman \\
& & (2000), Spiller and Hamilton (1993), \\
& & Smith and Moschis (1984) \\
Attitude & Satisfaction \\
No articles & No articles & Hare (2003) \\
Values & & Loyalty \\
No articles & & No articles \\
\hline
\end{tabular}

of health on shopping motivations and demonstrate that older individuals with poor health are more likely to seek convenience in their food shopping trips. In terms of the impact of biological aging on cognitive responses we also could identify only one result in the subcategory of perception. DeLorme et al. (2006) show that older individuals in the US with poor health perceive direct-to-consumer ads to have a stronger effect on other older consumers (third person effect). The biggest number of studies could be identified in the behavioral response categories. Smith and Moschis (1984) demonstrate that individuals with good health interact more frequently with mass media in the US. Spiller and Hamilton (1993) illustrate that heavy users of discounts in the US also possess good health (Spiller and Hamilton 1993). In terms of out-of-home mobility McMellon and Schiffman (2000) show that older US computer users with limitations in out-of-home mobility use the Internet more often to email and chat, to search for information or entertainment and to inform themselves about financial matters. Furthermore, Mathur and Moschis (2005) highlight that older US Americans who experience biological changes (lengthy hospitalization, chronic disease, hear impairment, etc.) spend more on cultural activity. In Finland, results of Kohijoki (2011) show that older consumers with health problems have more problems with transporting their food purchases. This goes in line with results of Hare (2003) on satisfaction in the UK. Here, elderly limited by health have a more dissatisfying shopping experience, due to problems with accessibility (Hare 2003).

\section{Results on the impact of psychological age on consumer behavior}

Measures of psychological age were applied in $18.75 \%$ of the analyzed articles and can again be divided into two groups: (1) measures of self-perceived age and (2) measures of memory and cognition. Most of the studies used so called cognitive age developed by (Barak and Schiffman 1981) to measure self-perceived age. Cognitive age combines the age a person feels, the age a person thinks he/she looks like, the age a person perceives him/herself to act, and the age a person perceives to be reflective of his/her 
Table 11 Consumer behavior topics investigated with psychological age

\begin{tabular}{|c|c|c|}
\hline $\begin{array}{l}\text { Affective and individual } \\
\text { responses }\end{array}$ & Cognitive responses & Behavioral responses \\
\hline Emotions & Use of information sources & Intentions \\
\hline Lee (2011) & Gwinner and Stephens (2001) & $\begin{array}{l}\text { Wolf et al. (2014), Moschis and } \\
\text { Mathur (2006), Tepper (1994) }\end{array}$ \\
\hline Motive and motivation & Perception & Behavior \\
\hline $\begin{array}{l}\text { Le Serre and Chevalier (2012), } \\
\text { Nam et al. (2007) }\end{array}$ & $\begin{array}{l}\text { Weijters and Geuens (2006), } \\
\text { Tepper (1994) }\end{array}$ & $\begin{array}{l}\text { Teller et al. (2013), Sudbury Riley } \\
\text { et al. (2012); Ong et al. (2009), } \\
\text { Mathur and Moschis (2005), } \\
\text { Szmigin and Carrigan (2000), } \\
\text { Wilkes (1992) }\end{array}$ \\
\hline Attitude & Information processing & Loyalty \\
\hline Smith and Moschis (1984) & $\begin{array}{l}\text { Johnson and Cobb-Walgren } \\
\text { (1994), Cole and } \\
\text { Balasubramanian (1993) }\end{array}$ & No articles \\
\hline Values & & Satisfaction \\
\hline $\begin{array}{l}\text { Kohlbacher and Chéron (2012), } \\
\text { Kohlbacher et al. (2011), } \\
\text { Sudbury and Simcock } \\
(2009 a, b)\end{array}$ & & No articles \\
\hline
\end{tabular}

interests. Other self-perceived age measures used were ideal age (2 studies) and age identity ( 2 studies). Ideal age represents the age a person wants to ideally feel, look, act, and have the interests of (Barak 1987). Age identity measures self-perceived age by categorizing the feel age of a person into counter age categories (e.g. young, middleaged, old) (Cavan et al. 1949). In comparison to self-perceived age, only two studies used measures of cognition and memory to assess psychological aging (Johnson and Cobb-Walgren 1994; Cole and Balasubramanian 1993). Cognition and memory were assessed using psychological tests of cognitive speed and working memory capacity. Regarding the investigated consumer responses, only studies investigating a direct psychological aging effect on consumer behavior were considered. Table 11 provides an overview of the researched consumer behavior areas using psychological age.

Several studies investigated the influence of cognitive aging on affective and individual consumer responses. In the context of emotions, Lee (2011) shows that a young self-perceived age has a positive effect on the psychological wellbeing of older consumers in the US. Looking at the impact of psychological age on motivation Nam et al. (2007) demonstrate that in the US older consumers, who feel younger than they are, are more fashion conscious. In the context of attitudes, results of Smith and Moschis (1984) indicate a positive relationship between self-perceived age and attitudes towards advertising in the US. In terms of research on values, Sudbury and Simcock (2009a, b) illustrate that people in the UK with young self-perceived ages place greater importance on values like warm relationships, fun, enjoyment, life, and self-fulfillment. In contrast, values like security, being well respected, sense of accomplishment, and a sense of belonging become more important with an increase in self-perceived age 
(Sudbury and Simcock 2009a, b). A result also confirmed in Japan by Kohlbacher and Chéron (2012), who show that the values excitement, fun and enjoyment in life, and sense of accomplishment are more important for persons who perceive themselves as younger than they chronologically are.

Regarding the influence of cognitive ageing on cognitive consumer responses, results demonstrate that elderly with young self-perceived ages seek new information (Gwinner and Stephens 2001). Furthermore, results of psychological influences of cognition and memory show that an age-related decline in cognitive speed influences negatively the recall of television advertisements (Johnson and Cobb-Walgren 1994) and that an age-related decline in working-memory capacity negatively influences the search and evaluation of products (Cole and Balasubramanian 1993).

Results of the influence of psychological age on behavioral consumer responses show that people with young self-perceived ages in the US intend to accept exclusive offers less likely (Wolf et al. 2014). Furthermore, cognitive age negatively influences fashion interest, entertainment activity, cultural activity, and volunteer related activities in the US (Wilkes 1992; Mathur and Moschis 2005). In Malaysia, Ong et al. (2009) find a negative relationship between cognitive age and patronage of defensive ageing products. In Austria, Teller et al. (2013) show that people with young perceived ages are less satisfied with stores with good maneuverability, good product range, and a nice atmosphere.

\section{Results on the impact of social age on consumer behavior}

Social age measures were applied in $7 \%$ of the identified articles. Only two roles associated with social aging were investigated. Seven studies measured the influence of retirement on consumer behavior and two studies the influence of grandparenthood. Table 12 provides an overview of all researched consumer behavior areas using social age.

Regarding the impact social aging on affective and individual responses, only studies in the subcategory attitude could be identified. Walker and Mackling (1992) show that US grandmothers have more positive attitudes toward ads in which they are shown in a traditional role in the "centre" of the family. Burnett (1996) found that retirees in the US have a negative attitude towards credit.

In terms of influences on cognitive responses, Wolf et al. (2014) demonstrate that retirees who identify more with their peers perceive age-related labels more positively. Furthermore, results by Stammerjohan et al. (2007) indicate that in the transition of retirement, retiree wives participate more in problem recognition and information search than post-transition wifes.

Looking at the impact of social aging on behavioral responses, Wolf et al. (2014) show that retirees who identify with their peers have a stronger intend to use ageexclusive offers. Burnett (1989) demonstrates that retirees exercise more, shop more for clothes/groceries, join more often clubs, entertain themselves more, do more volunteer work, are more likely to take good care of themselves, are more likely to return unsatisfactory products, shop more via mail, and go out more with their spouse. Furthermore, retirees do more impulse buying (Burnett 1996). Hopkins et al. (2006) show 
Table 12 Consumer behavior topics investigated with social age

\begin{tabular}{|c|c|c|}
\hline $\begin{array}{l}\text { Affective and individual } \\
\text { responses }\end{array}$ & Cognitive responses & Behavioral responses \\
\hline Emotions & Use of information sources & Intentions \\
\hline No articles & Moschis et al. (1993) & $\begin{array}{l}\text { Wolf et al. (2014) and Walker and } \\
\text { Macklin (1992) }\end{array}$ \\
\hline Motive and motivation & Perception & Behavior \\
\hline No articles & Wolf et al. (2014) & $\begin{array}{l}\text { Sudbury Riley et al. (2012), Tootelian } \\
\text { and Varshney (2010), Hopkins et al. } \\
\text { (2006), Burnett (1996), Burnett } \\
\text { (1989), Fox et al. (1984) }\end{array}$ \\
\hline Attitude & Information processing & Loyalty \\
\hline $\begin{array}{l}\text { Burnett (1996), Moschis et al. } \\
\text { (1993), Walker and Macklin } \\
\text { (1992) }\end{array}$ & $\begin{array}{l}\text { Stammerjohan et al. (2007) } \\
\text { and Montgomery et al. } \\
\text { (1998) }\end{array}$ & No articles \\
\hline Values & & Satisfaction \\
\hline No articles & & No articles \\
\hline
\end{tabular}

that retirees in the US who see retirement as a new start in their life or perceive retirement as a disruption of their previous life, spend more on active/outward-oriented products. Retirees who experience retirement as the beginning of "old age" or see retirement as continuation of their previous life spend more on passive/inward-oriented products (Hopkins et al. 2006). Tootelian and Varshney (2010) illustrate that US grandparents spend an average of $\$ 1026.98$ per annum on their grandchildren. The highest percentage of grandparents spend on presents and the lowest percentage on travel and vacations. Average amount spent was highest for travel and vacations and lowest for school supplies (Tootelian and Varshney 2010).

\section{Results on the impact of life circumstances on consumer behavior}

Life circumstances in form of the impact of generations were measured in $6.25 \%$ of the analyzed studies. All identified studies compare the Baby Boomer (1946-1965) generation with younger generations like the Generation X (1966-1985) or the Generation Y (1986-2005). Table 13 provides an overview of all researched consumer behavior areas using life circumstances.

Several studies investigated the influence of life circumstances on affective and individual consumer responses. In the context of motivations, results of Anders (2013) show that Baby Boomers value retail experience and in-store service higher than members of Generation Y (Anders 2013). Regarding the impact of life circumstances on attitudes Loroz and Helgeson (2013) illustrate that Baby Boomers have more positive attitudes towards environmental focus appeals than Generation Y consumers, but less positive attitudes toward image appeals, extravagance appeals, sex appeals, and greed appeals. In terms of research on values, Baby Boomers are less materialistic than Generation Y consumers (Loroz and Helgeson 2013). Results on the impact on 
Table 13 Consumer behavior topics investigated with life circumstances

\begin{tabular}{lll}
\hline $\begin{array}{l}\text { Affective and individual } \\
\text { responses }\end{array}$ & Cognitive responses & Behavioral responses \\
\hline $\begin{array}{l}\text { Emotions } \\
\text { No articles } \\
\text { Motive and motivation }\end{array}$ & Use of information sources & Intentions \\
$\begin{array}{l}\text { Anders (2013), Worsley } \\
\text { et al. (2011) }\end{array}$ & Harmon et al. (1999) & No articles \\
& Kumar and Lim (2008) & Behavior \\
$\begin{array}{l}\text { Attitude } \\
\text { Loroz and Helgeson (2013), } \\
\text { Reisenwitz and Iyer (2007) } \\
\text { Values }\end{array}$ & No articles & (2012), Yang and Jolly (2008), \\
Loroz and Helgeson & & $\begin{array}{c}\text { Reisenwitz and Iyer (2007) } \\
\text { (2013) }\end{array}$ \\
\hline
\end{tabular}

cognitive responses indicate that perceived economic value has a greater effect on satisfaction for Baby Boomers than for Generation Y consumers (Kumar and Lim 2008). Impacts of generational cohorts on behavior demonstrate that Baby Boomers start the purchase process with choosing a retailer they trust. Generation Y consumers, on the other hand, begin the process with choosing a product (Anders 2013). Furthermore, Yang and Jolly (2008) demonstrate that baby boomers have more difficulty to use mobile data services than Generation X consumers. Eastman and Liu (2012) demonstrate that Baby Boomers have a lower level of status consumption than Generation Y consumers (Eastman and Liu 2012).

\section{Results on the impact of life events on consumer behavior}

Only $3.9 \%$ of all analyzed studies investigated the impact of life events on consumer behavior. Life events were typically measured with life events scale consisting of 1025 transitional life events. Table 14 provides an overview of the researched consumer behavior areas using life events.

Regarding the impact of life events on consumer behavior only behavioral responses were investigated. In this context, only one impact of life events on consumer behavior could be demonstrated. Mathur et al. (1999) illustrate that the experience of stressful life events leads to emotion-focused consumption-coping behaviors.

\section{Conclusion and implications for future research}

In general, the results demonstrate that chronological age is still the most widely used measure of aging in consumer behavior. 127 of 128 studies used chronological age. Notably, 36 of these 127 studies were non-comparative studies, solely defining chronologically older consumer group(s) without comparing them to younger ones 
Table 14 Consumer behavior topics investigated with life events

\begin{tabular}{lll}
\hline $\begin{array}{l}\text { Affective and individual } \\
\text { responses }\end{array}$ & Cognitive responses & Behavioral responses \\
\hline Emotions & Use of information sources & Intentions \\
No articles & No articles & No articles \\
Motive and motivation & Perception & Behavior \\
No articles & No articles & Ong and Moschis (2009); Mathur and \\
& & Moschis (2005), Mathur et al. (1999), \\
& Information processing & Loyalty \\
Attitude & No articles & No articles \\
No articles & & Satisfaction \\
Values & & No articles \\
No articles & & \\
\hline
\end{tabular}

or researching any age influence within them. These studies are clearly running the risk to false interpretations as already mentioned by Tongren (1988) and should be definitely avoided in future research efforts.

Furthermore, the review demonstrates that those studies using chronological age to compare younger and older consumers do provide valuable insights on consumer behavior changes caused by aging. Based on the presented results, with increasing chronological age consumers perceive communication differently and change their motivations and behavior in the marketplace. However, inconsistencies between studies researching similar topics can be observed. Results indicate for instance, a need for convenience and a more localized shopping behavior, but do also demonstrate a preference for large retailing sites located outside of communities and town centers. Also, for example, in terms of the use of information sources, it is not clear if chronological age leads to a decrease or increase in media usage. A reason for the observed differences lies in the multidimensionality of the aging process itself, which can be hardly covered by the chronological age measure. The use of non-chronological age measures reveals "hidden" factors causing the detected discrepancies in this context. Studies investigating, for example, the influence of biological aging demonstrate a relationship between health and the need for convenience or the use of different forms of mass media. However, very few studies provide a holistic approach, integrating several age-related factors to investigate rigidly a specific construct (e.g. convenience) in a given context. Such approaches are strongly recommended for future research efforts and could also help to determine the relative importance of certain groups and their needs within the older consumer group (e.g. people with poor health).

Surprisingly, alternative measures other than chronological age have been used in only $38.3 \%$ (49 studies) of all identified studies. Because of this relatively small amount of research dealing with alternative perspectives on aging, we do not agree that the focus on specific aspects of the aging process does not lead to satisfactory theory building. Insights on how older consumers perform cognitively during different times of day or on how the stage of retirement and associated lifestyles change consumption 
are valuable steps towards better theory building in older consumer research. Our results show that research with alternative age measures is still in an early, exploratory stage and every future study investigating the impact of age-related factors (even just one age-related factor) can help to get a "brighter", more conclusive picture of the older consumer.

However, as mentioned by previous reviews (e.g. Moschis 2012) it is conceptually and empirically complex to combine facets of the aging process and the use of cross-sectional data leads to the problem that aging effects cannot be detangled from period or cohort effects. The multitheoretical model of the Life-Course Paradigm, takes into account several factors of aging and overcomes these complex relationships (for a detailed discussion see Moschis 2012). Generally, it is advisable to implement such a paradigm and the associated methods in future research efforts, but they should also be seen as a "gold standard" because of their data requirements. Most of the time longitudinal data is needed for these approaches, making research expensive and time-consuming. This could be especially troublesome for researchers, who are in the early stages of developing a career. Therefore, we propose a pragmatic course of action regarding the use of the Life-Course Paradigm. Future research on already more elaborated topics, where results on the influence of biological, psychological, and social aging are present can focus on the interrelation of the detected effects and the impact of time and context, using the Life-Course Paradigm. Future research on exploratory topics, where basic influences like chronological age have been researched and may have led to contradicting results can be investigated also with more "pure" approaches using one or more age-related factors. The review at hand can help researchers to identify and assess research areas according to this rule of thumb.

Regarding the investigated consumer behavior responses, results of the review show, that investigations of the impact of chronological and psychological age have been conducted in all three categorized areas of consumer behavior (behavioral responses, cognitive responses, and affective responses). In context of psychological age, especially the impact of subjective aging has been in the focus of research efforts. Only two studies measured age-related changes in cognitive functioning. A surprising result given, for example, the aforementioned discrepancies between results on the impact of chronological age on media usage. We believe future studies should incorporate measures of cognitive functioning to gain deeper insights on the information process of older consumers. Furthermore, few substantial quantitative results on the impact of biological age on affective and cognitive responses in consumer behavior could be found. Also the impact of social aging on affective and cognitive responses seems to be an under-researched area. This is especially surprising given the fact that previous reviews already mentioned a need for studies in these areas (Moschis 1991, 1994; Gregoire 2003; Moschis 2012). Also, qualitative research results of Schau et al. (2009) indicate an impact of social role loss on emotions and consumer identity. Quantitative results of Drolet et al. (2007), Williams and Drolet (2005) and Jayanti (2010) emphasize the special role of emotions for older consumers in communication efforts. Based on our results, we repeat the proposition of previous reviews and recommend to foster quantitative research on the impact of biological and social aging on emotions and cognitive processes. Furthermore, we also see a lack of studies on the impact of life events and life circumstances on consumer behavior. A surprising development, given 
the observed differences in results between countries in the review. Research on life circumstances and life events could clarify if these influences are associated to cultural differences in the aging process. In this context, the aforementioned Life-Course Paradigm appears to be a promising approach to dismantle the effects of time and context and assess the importance of cultural effects on the older consumer.

Based on our review, we also noticed that measurement of aging differs widely within aging dimensions, and results from different studies can hardly be compared and/or summarized. We believe that this situation could be an explanation for the intensive usage of chronological age as "meta-measure" integrating all aging dimensions. Chronological age is a parsimonious measure approach, given the time-constraints in quantitative empirical research. Therefore, we see a need for studies on the measurement properties of different age dimensions' measures. Studies like the one of Wilkes (1992) on cognitive aging should be done on every age dimension. Results of these studies can provide approaches for a more unified measurement of aging in the future and can also clarify relationships between age dimension measures. In addition, an empirical meta-analysis (see Martin 2015) of previous results could lead to interesting insights on the relative impact of age-related factors on the knowledge development in the field.

\section{Limitations}

The review at hand is a systematic approach in searching and selecting literature along several dimensions: (1) choice of databases, (2) search terms, (3) quality of publication outlets, and (4) research design. However, despite implementing a very detailed, systematic, and thorough process, a typical limitation associated with such an approach is the lack of absolute proof that all relevant literature is covered by the review. Further reviews, could extend the number of databases, search terms, and also include qualitative work to provide an even more holistic picture of the research field.

Furthermore, the qualitative categorization of the investigated consumer behavior variables can be considered as one of the most challenging tasks of the review at hand due to the multidimensionality of consumer responses in general and due to the multifaceted theoretical backgrounds of the investigated constructs. Therefore, the implemented categorization scheme is not to be intended to be the only, unquestioned scheme. It is, based on previous literature, our best try to theoretically group the identified literature. By doing so it fulfills the purpose of the review at hand and helps to structure results and identify research gaps. However, we understand that our readers do not have to follow our worldview. Therefore, the results on consumer responses can be broken down into the defined subgroups. This procedure gives every reader the chance to personally group the identified subgroups according to his or her own conceptual background.

Despite the limitations outlined above, our review provides a unique and exhaustive summary of relevant quantitative research in consumer behavior. We believe it builds a solid base for the analysis of previous research efforts and helps to guide and intensify future research projects on older consumers. 
Acknowledgements Open access funding provided by Vienna University of Economics and Business (WU).

Open Access This article is distributed under the terms of the Creative Commons Attribution 4.0 International License (http://creativecommons.org/licenses/by/4.0/), which permits unrestricted use, distribution, and reproduction in any medium, provided you give appropriate credit to the original author(s) and the source, provide a link to the Creative Commons license, and indicate if changes were made.

\section{References}

Andreasen AR (1984) Life status changes and changes in consumer preferences and satisfaction. J Consum Res 11(3):784-794

Angell R, Megicks P, Memery J, Heffernan T (2014) Older shopper types from store image factors. J Retail Consum Serv 21(1):192-202

AT Kearney (2010) What do mature consumers want?. Global Business Policy Council, AT Kearney, Virginia

Barak B (1987) Cognitive age: a new multidimensional approach to measuring age identity. Int J Aging Hum Dev 25(2):109-128

Barak B, Schiffman LG (1981) Cognitive age: a nonchronological age variable. Adv Consum Res 8 (1):602606

Beneke J, Frey N, Chapman R, Mashaba N, Howie T (2011) The grey awakening: a South African perspective. J Consum Mark 28(2):114-124

Booth A, Papaioannou D, Sutton A (2012) Systematic approaches to a successful literature review. Sage, London

Bernhardt KL (1981) Consumer problems and complaint actions of older Americans: A national view. J Retail 57(3):107-123

Brennant C, Ritch E (2010) Capturing the voice of older consumers in relation to financial products and services. Int J Consum Stud 34(2):212-218

Burnett JJ (1991) Examining the media habits of the affluent elderly. J Advert Res 31(5):33-41

Burnett JJ (1996) Direct marketing usage by older men: Chronological age versus retirement. J Direct Mark 10(2):56-66

Burt S, Gabbott M (1995) The elderly consumer and non-food purchase behavior. Eur J Mark 29(2):43-57

Cavan RS, Burgess EW, Havighurst, RJ, Goldhamer H (1949) Personal adjustment in old age. Science Research Associates, Inc, Oxford

Cole CA, Balasubramanian SK (1993) Age differences in consumers' search for information: public policy implications. J Consum Res 20(1):157-169

Cole CA, Gaeth GJ (1990) Cognitive and age-related differences in the ability to use nutritional information in a complex environment. J Mark Res 27(2):175-184

Cooper HM (1988) Organizing knowledge syntheses: a taxonomy of literature reviews. Knowl Soc 1(1):104126

Dean AM, Rolland SE (2011) Using an age-based lens to test the antecedents of value in retail. Der Mark 51:85-100

DeLorme DE, Huh J, Reid LN (2006) Perceived effects of direct-to-consumers (DTC) prescription drug adverstising on self and others. J Advert 35(3):47-65

Drolet A, Williams P, Lau-Gesk L (2007) Age-related differences in responses to affective vs. rational ads for hedonic vs. utilitarian products. Mark Lett 18(4):211-222

East R, Uncles M, Lomax W (2014) Hear nothing, do nothing: the role of word of mouth in the decisionmaking of older consumers. J Mark Manag 30(7-8):786-801

Eastman JK, Iyer R (2004) The elderly's uses and attitudes towards the Internet. J Consum Mark 21(2/3):208-220

Eastman JK, Liu J (2012) The impact of generational cohorts on status consumption: an exploratory look at generational cohort and demographics on status consumption. J Consum Mark 29(2):93-102

Eisend M (2015) Have we progressed marketing knowledge ? A meta-meta-analysis of effect sizes in marketing research. J Mark 79(3):23-40

Engel JF, Kollat DT, Roger D (1968) Consumer Behavior. Blackwell, Oxford

Ensley EE, Pride William M (1991) Advertisement pacing and the learning of marketing information by the elderly. Psychol Mark 8(1):1-20 (1986-1998) 
Ferguson R, Brohaugh B (2010) The aging of Aquarius. J Consum Mark 27(1):76-81

Fink A (2010) Conducting research literature review from the Internet to paper, 3rd edn. Sage, Los Angeles, California

Fox MC, Roscoe AM, Feigenbaum AM (1984) A longitudinal Analysis of Consumer Behavior in the Elderly Population. Adv Consum Res 11:563-568

Gentry, JW, Kennedy PF (1995) Marketing implications of the expected role of physicians in family decisions concerning the institutionalization of the elderly. Psychol Mark 12(7):647-662 (1986-1998)

Goodrich K (2013) Effects of age and time of day on internet advertising outcomes. J Mark Commun 19(4):229-244

Gorn GJ, Goldberg ME, Chattopadhyay A, Litvack D (1991) Music and information in commercials: their effects with an elderly sample. J Advert Res 31(5):23-32

Greco AJ, Johnson EB, Swayne LE (1997) Will older models turn off shoppers? Int J Advert 16(1):27-36

Greco AJ, Swayne LE (1992) Sales response of elderly consumers to point-of-purchase advertising. J Advert Res 32(5):43-53

Greenberg S (2011) A profile of older Americans. Administration on Aging of the US, Department of Health and Human Services, Washington DC

Gregoire Y (2003) The impact of aging on consumer responses. Adv Consum Res 30:19-26

Guiot D (2001) Antecedents of subjective age biases among senior women. Psychol Mark 18(10):1049-1071

Gwinner KP, Stephens N (2001) Testing the implied mediational role of cognitive age. Psychol Mark 18(10):1031-1048

Hare C (2003) The food-shopping experience: a satisfaction survey of older Scottish consumers. Int J Retail Distrib Manag 31(5):244-255

Harmon HH, Webster RL, Weyenberg S (1999) Marketing medium impact: differences between baby boomers and generation Xers in their information search in a variety of purchase decision situations. J Mark Commun 5(1):29-38

Harzing AW (2015) J Qual List. http://www.hartzing.com(online)

Hopkins CD, Roster CA, Wood CM (2006) Making the transition to retirement: appraisals, post-transition lifestyle, and changes in consumption patterns. J Consum Mark 23(2):89-99

Iyer R, Eastman JK (2006) The elderly and their attitudes toward the internet: the impact on internet use, purchase, and comparison shopping. J Mark Theory Pract 14(1):57-67

Jahn S, Gaus H, Kiessling T (2012) Trust, commitment, and older women: exploring brand attachment differences in the elderly segment. Psychol Mark 29(6):445-457

Javalgi RG, Thomas EG, Rao SR (2000) Meeting the needs of the elderly in the financial services marketplace: an empirical analysis. J Prof Serv Mark 20(2):87-105

Jayanti RK (2010) accentuate the positive: elderly responses to health communications. J Mark Theory Pract 18(3):263-273

Johnson RL, Cobb-Walgren CJ (1994) Aging and the problem of television clutter. J Advert Res 34(4):54-62

Johnson-Hillery J, Kang J, Tuan WJ (1997) The difference between elderly consumers' satisfaction levels and retail sales personnel's perceptions. Int J Retail Distrib Manag 25(4):126-137

Jones SC, Mullan J (2006) Older adults' perceptions and understanding of direct-to-consumer advertising. J Consum Mark 23(1):6-14

Keillor BD, Parker R, Erffmeyer RC (1996) The evaluative criteria of the elderly in a retail experience: product-related vs. store-related factors. J Mark Manag 6(2):61-71 (10711988)

Kim YK, Kang J, Kim M (2005) The relationships among family and social interaction, loneliness, mall shopping motivation, and mall spending of older consumers. Psychol Mark 22(12):995-1015

Kim S, Kim H, Gon Kim W (2003) Impacts of senior citizens' lifestyle on their choices of elderly housing. J Consum Mark 20(2/3):210-226

Klippel E (1974) Marketing research and the aged consumer: the need for a new perspective. J Acad Mark Sci 2(1):242-248

Kohijoki AM (2011) The effect of aging on consumer disadvantage in grocery retail services among the Finnish elderly. J Retail Consum Serv 18(4):370-377

Kohijoki AM, Marjanen H (2013) The effect of age on shopping orientation-choice orientation types of the ageing shoppers. J Retail Consum Serv 20(2):165-172

Kohlbacher F, Chéron E (2012) Understanding silver consumers through cognitive age, health condition, financial status, and personal values: Empirical evidence from the world's most mature market Japan. J Consum Behav 11(3):179-188 
Kohlbacher F, Sudbury L, Hofmeister A (2011) Using self-perceived age and the list of values to study older consumer in 4 nations. Adv Consum Res 39:341-346

Kumar A, Lim H (2008) Age differences in mobile service perceptions: comparison of generation Y and baby boomers. J Serv Mark 22(7):568-577

Kwon HJ, Beamish J (2014) Segmentation analysis of US older adults living in multifamily housing: reasons for moving. Int J Consum Stud 38(4):427-434

Lambert-Pandraud R, Laurent G (2010) Why do older consumers buy older brands? The role of attachment and declining innovativeness. J Mark 74(5):104-121

Lambert-Pandraud R, Laurent G, Lapersonne E (2005) Repeat purchasing of new automobiles by older consumers: empirical evidence and interpretations. J Mark 69(2):97-113

Laukkanen T, Sinkkonen S, Marke K, Laukkanen P (2007) Innovation resistance among mature consumers. J Consum Mark 24(7):419-427

Le Serre D, Chevalier C (2012) Marketing travel services to senior consumers. The J Consum Mark 29(4):262-270

Le Serre D, Legohérel P, Weber K (2013) Seniors' motivations and perceived risks: a cross-cultural study. J Int Consum Mark 25(2):61-79

Lee Young- A (2011) Clothing as an environment for older adults' successful ageing. Int J Consum Stud 35(6):702-710

Lee TJ, Cho H, Ahn TH (2012) Senior citizen satisfaction with restaurant service quality. J Hosp Mark Manag 21(2):215-226

Lee YA, Sontag MS (2010) An assessment of the proximity of clothing to self scale for older persons. Int J Consum Stud 34(4):443-449

Loroz PS, Helgeson JG (2013) Boomers and their babies: an exploratory study comparing psychological profiles and adverstising appeal effectiveness across two generations. J Mark Theory Pract 21(3):289_ 306

Lu Y, Seock YK (2008) The influence of grey consumers' service quality perception on satisfaction and store loyalty behavior. Int J Retail Distrib Manag 36(11):901-918

Lumpkin JR, Greenberg BA (1982) Apparel-Shopping Patterns of the Elderly Consumer. J Retail 58(4):6889

Lumpkin JR, Greenberg BA, Goldstucker JL (1985) Marketplace Needs of the Elderly: Determinant Attributes and Store Choice. J Retail 61(2):75-105

Lyon P, Mattsson SY, Fjellström C, Janhonen-Abruquah H, Monika S, Anne C (2011) Continuity in the kitchen: how younger and older women compare in their food practices and use of cooking skills. Int J Consum Stud 35(5):529-537

Mathur A, Moschis GP (2005) Antecedents of cognitive age: a replication and extension. Psychol Mark 22(12):969-994

Mathur A, Moschis GP, Lee E (1999) Stress and consumer behavior coping strategies of older adults. J Mark Pract 5(6/7/8):233-247

Mathur A, Moschis GP, Lee E (2003) Life events and brand preference changes. J Consum Behav 3:129-141

Mathur A, Moschis GP, Lee E (2008) A longitudinal study of the effects of life status changes on changes in consumer preferences. J Acad Mark Sci 36:234-246

Mathur A, Sherman E, Schiffman LG (1998) Opportunities for marketing travel services to new-age elderly. J Serv Mark 12(4):265-277

Mayring P (2010) Qualitative Inhaltsanalyse-Grundlagen und Techniken, 11th edn. Beltz, Weinheim

McMellon CA, Schiffman LG (2000) Cybersenior mobility: why some older consumers may be adopting the internet. Adv Consum Res 27(1):139-144

Meneely L, Burns A, Strugnell C (2009a) Age associated changes in older consumers retail behaviour. Int J Retail Distrib Manag 37(12):1041-1056

Meneely L, Strugnell C, Burns A (2009b) Elderly consumers and their food store experiences. J Retail Consum Serv 16(6):458-465

Merz J, Hanglberger D, Rucha R (2010) The timing of daily demand for goods and services-microsimulation policy results of an aging society, increasing labour market flexibility, and extended public childcare in Germany. J Consum Policy 33(2):119-141

Miller NJ, Kim S, Schofield-Tomschin S (1998) The effects of activity and aging on rural community living and consuming. J Consum Aff 32(2):343-368

Milner T, Rosenstreich D (2013) Insights into mature consumers of financial services. J Consum Mark 30(3):248-257 
Montgomery RD, Taylor RD, Mitchell MA (1998) The impact of retirement, occupation, and activity on the cognitive processes of the Elderly. J Mark Manag 8(2):52-65

Moschis GP (1991) Approaches to the study of consumer behavior in late life. Adv Consum Res 18(1):517520

Moschis GP (1992) Gerontographics: a scientific approach to analyzing and targeting the mature market. J Serv Mark 6(3):17-26

Moschis GP (1994) Consumer behavior in later life: multidisciplinary contributions and implications for research. J Acad Mark Sci 22(3):195-204

Moschis GP (1996) Gerontographics: life-stage segmentation for marketing strategy development, Westport

Moschis GP (2003) Marketing to older adults: an updated overview of present knowledge and practice. J Consum Mark 20(6):516-525

Moschis GP (2012) Consumer behavior in later life: current knowledge, issues, and new directions for research. Psychol Mark 29(2):57-75

Moschis GP, Bellenger D, Carolyn FC (2003) Financial service preferences and patronage motives of older consumers. J Financ Serv Mark 7(4):331-340

Moschis GP, Ong FS (2011) Religiosity and consumer behavior of older adults: a study of subcultural influences in Malaysia. J Consum Behav 10(1):8-17

Moschis GP, Pettigrew S (2010) Understanding consumer well-being in later life: Business strategies for enhancing quality of life. In: Kohlbacher F, Herstatt C (eds) The silver market phenomenon, 2nd edn. Springer, New York, pp 229-237

Moschis GP, Curasi C, Bellenger D (2004) Patronage motives of mature consumers in the selection of food and grocery stores. J Consum Mark 21(2/3):123-133

Moschis GP, Ferguson JL, Zhu M (2011) Mature consumers' selection of apparel and footwear brands and department stores. Int J Retail Distrib Manag 39(10):785-801

Moschis GP, Mathur A (2006) Older consumer responses to marketing stimuli: the power of subjective age. J Advert Res 46(3):339-346

Moschis GP, Mathur A (2007) Baby boomers and their parents: Surprising findings about their lifestyles, mindsets, and well-being. Paramount Books, Ithaca, NY

Moschis GP, Mathur A, Smith RB (1993) Older consumers' orientations toward age-based marketing stimuli. J Acad Mark Sci 21(3):195-205

Moschis GP, Nguyen HV (2008) Affluent mature consumers: preference and patronisation for financial services. J Financ Serv Mark 13(3):259-267

Moschis GP, Weaver ST (2010) Segmenting demand for long-term care insurance among mature consumers. Serv Mark Q 31(1):106-115

Mulrow C (1994) Rationale for systematic reviews. Br Med J 309(6954):597

Murrell SA, Norris F, Grote C (1988) Life events in older adults. In: Cohen LH (ed) Life events and psychological functioning. Sage, California, pp 96-122

Nam J, Hamlin R, Gam HJ, Kang JH, Kim J, Kumphai P, Starr C, Richards L (2007) The fashion-conscious behaviours of mature female consumers. Int J Consum Stud 31(1):102-108

Nasco SA, Hale D, Thomas M (2012) Mature consumers speak: insights on information search and selfefficacy for service purchases. Serv Mark Q 33(2):119-137

Niemelä-Nyrhinen J (2007) Baby boom consumers and technology: shooting down stereotypes. J Consum Mark 24(5):305-312

Oates B, Shufeldt L, Vaught B (1996) A psychographic study of the elderly and retail store attributes. J Consum Mark 13(6):14-27

Ong FS, Kitchen JP, Jama AT (2008) Consumption patterns and silver marketing: an analysis of older consumers in Malaysia. Mark Intell Plan 26(7):682-698

Ong FS, Moschis GP (2009) Stress, coping, and well-being: a study of ethnic differences among older adults. J Int Consum Mark 21(3):219-229

Ong FS, Yap-Ying L, Abessi M, Phillips D (2009) The correlates of cognitive ageing and adoption of defensive-ageing strategies among older adults. Asia Pac J Mark Logist 21(2):294-305

Parment A (2013) Generation Y vs. baby boomers: shopping behavior, buyer involvement and implications for retailing. J Retail Consum Serv 20(2):189-199

Pettigrew S, Mizerski K, Donovan R (2005) The three "big issues" for older supermarket shoppers. J Consum Mark 22(6):306-312

Phillips WMJ, Jang SC (2012) Exploring seniors' casino gaming intention. J Hosp Tour Res 36(3):312-334 
Phillips L, Sternthal B (1977) Age Differences in information processing: a perspective on the aged consumer. J Mark Res 14(4):444-457

Prayag G (2012) Senior travelers' motivations and future behavioral intentions: the case of nice. J Travel Tour Mark 29(7):665-681

Reisenwitz T, Iyer R, Kuhlmeier DB, Eastman JK (2007) The elderly's internet usage: an updated look. J Consum Mark 24(7):406-418

Reisenwitz T, Iyer R (2007) A comparison of younger and older baby boomers: investigating the viability of cohort segmentation. J Consum Mark 24(4):202-213

Saba A, Messina F, Turrini A, Lumbers M, Raats MM (2008) Older people and convenience in meal preparation: a European study on understanding their perception towards vegetable soup preparation. Int J Consum Stud 32(2):147-156

Sachan A, Datta S (2005) Review of supply chain management and logistics research. Int J Phys Distrib Logist Manag 35(9):664-705

Schewe C (1984) Buying and consuming behaviors of the elderly: findings from behavioral research. Adv Consum Res 11(1):558-562

Schau HJ, Gilly MC, Wolfinbarger M (2009) Consumer identity renaissance: the resurgence of identityinspired consumption in retirement. J Consum Res 36(2):255-276

Sherman E, Schiffman LG, Mathur A (2001b) The influence of gender on the new-age elderly's consumption orientation. Psychol Mark 18(10):1073-1089

Shufeldt L, Oates B, Vaught B (1998) Is lifestyle an important factor in the purchase of OTC drugs by the elderly? J Consum Mark 15(2):111-124

Silvera DH, Meyer T, Laufer D (2012) Age-related reactions to a product harm crisis. The J Consum Mark 29(4):302-309

Silvers C (1997) Smashing old sterotypes of 50-plus America. J Consum Mark 14(4/5):303-309

Simcock P, Sudbury L, Wright G (2006) Age, perceived risk and satisfaction in consumer decision making: a review and extension. J Mark Manag 22(3/4):355-377

Singh J, Riley FD, Hand C, Maeda M (2012) Measuring brand choice in the older customer segment in Japan. Int J Market Res 54(3):347-368

Smith RB, Moschis GP (1984) Consumer Socialization of the Elderly: An Exploratory Study. Adv Consum Res 11:548-552

Spiller LD, Hamilton RA (1993) Senior citizen discount programs: which seniors to target and why. J Consum Mark 10(1):42-51

Stammerjohan CA, Capella LM, Taylor RD (2007) Retirement and transition phenomena in the family purchase process. Psychol Mark 24(3):225-251

Stephens N (1991) Cognitive age: a useful concept for advertising? J Advert 20(4):37-48

Strutton HD, Lumpkin JR (1992) Information sources used by elderly health care product adopters. J Advert Res 32(4):20-30

Sudbury L, Simcock P (2009a) A multivariate segmentation model of senior consumers. J Consum Mark 26(4):251-262

Sudbury L, Simcock P (2009b) Understanding older consumers through cognitive age and the list of values: a UK-based perspective. Psychol Market 26(1):22-38

Sudbury Riley L, Kohlbacher F, Hofmeister A (2012) A cross-cultural analysis of pro-environmental consumer behaviour among seniors. J Mark Manag 28(3-4):290-312

Szmigin I, Carrigan M (2000) The older consumer as innovator does cognitive age hold the key? J Mark Manag 16(5):505-527

Teller C, Gittenberger E (2011) Patronage behaviour of elderly supermarket shoppers-antecedents and unobserved heterogeneity. Int Rev Retail Distrib Consum Res 21(5):483-499

Teller C, Gittenberger E, Schnedlitz P (2013): Cognitive age and grocery-store patronage by elderly shoppers. J Mark Manag:1-21 (2016) (ahead-of-print)

Tepper K (1994) The role of labeling processes in elderly consumers' responses to age segmentation cues. J Consum Res 20(4):503-519

Tongren H (1988) Determinant behavior characteristics of older consumers. J Consum Aff 22(1):136-157

Tootelian DH, Varshney SB (2010) The grandparent consumer: a financial "goldmine" with gray hair? J Consum Mark 27(1):57-63

Tynan C, Drayton J (1985) The methuselah market part II: decision making and the older consumer. J Mark Manag 1(2):213-221

Uncles MD, Ehrenberg ASC (1990) Brand Choice Among Older Consumers. J Advertising Res 30(4):19-22 
Uncles M, Lee D (2006) Brand purchasing by older consumers: an investigation using the juster scale and the dirichlet model. Mark Lett 17(1):17-30

United Nations (2013) World Population Ageing. Department of Economic and Social Affairs, New York

Van Auken S, Barry TE (2009) Assessing the nomological validity of a cognitive age segmentation of Japanese seniors. Asia Pac J Mark Logist 21(3):315-328

Vienna Institute of Demography (VID) and International Institute forApplied Systems Analysis (IIASA) (2016) European DemographicDatasheet. Wittgenstein Centre (IIASA, VID/OEAW, WU), Vienna

Vuori S, Holmlund-Rytkönen M (2005) 55+ people as internet users. Mark Intell Plan 23(1):58-76

Walker MM, Macklin MC (1992) The use of role modeling in targeting advertising to grandparents. J Advert Res 32(4):37-44

Wägar K, Lindqvist LJ (2010) The role of the customer contact person's age in service encounters. J Serv Mark 24(7):509-517

Weijters B, Geuens M (2006) Evaluation of age-related labels by senior citizens. Psychol Mark 23(9):783798

Wilkes RE (1992) A structural modeling approach to the measurement and meaning of cognitive age. J Consum Res 19(2):292-301

Wilkie WL, Moore ES (2003) Scholarly Research in Marketing: Exploring the "4 Eras" of Thought Development. J Public Policy Mark 22(2):116-146

Williams P, Drolet A (2005) Age-related differences in responses to emotional advertisements. J Consum Res 32(3):343-354

Wilson LC, Alexander A, Lumbers M (2004) Food access and dietary variety among older people. Int J Retail Distrib Manag 32(2/3):109-122

Wolf F, Sandner P, Welpe I (2014) Why do responses to age-based marketing stimuli differ? The Influence of Retirees' Group Identification and changing consumption patterns identification and changing consumption patterns. Psychol Mark 31(10):914-931

Worsley T, Chun Wang W, Hunter W (2011) Baby boomers' reasons for choosing specific food shops. Int J Retail Distrib Manag 39(11):867-882

Yang K, Jolly LD (2008) Age cohort analysis in adoption of mobile data services: gen Xers versus baby boomers. J Consum Mark 25(5):272-280

Yang Z, Zhou N, Chen J (2005) Brand choice of older Chinese consumers. J Int Consum Mark 17(4):65-81

Yoon C (1997) Age differences in consumers' processing strategies: an investigation of moderating influences. J Consum Res 24(3):329-342

Yoon C, Lee MP, Danziger S (2007) The effects of optimal time of day on persuasion processes in older adults. Psychol Mark 24(5):475-495

Yoon C, Cole C, Lee MP (2009) Consumer decision making and aging: current knowledge and future directions. J Consum Psychol 19(1):2-16 